\title{
ANALYSIS UNDERSTANDING OF CONCEPT IN SOUND WAVE MATERIALS AND LIGHT WAVES IN CLASS XI SENIOR HIGH SCHOOL STUDENTS TAMPAN PEKANBARU
}

\author{
Nindri Resti Nova ${ }^{* 1)}$, Fakhruddin ${ }^{2)}$, Yennita ${ }^{3)}$ \\ ${ }^{1,2,3)}$ Physics Education, University of Riau \\ email: ") nindri.resti@gmail.com \\ faruqfisika@yahoo.com \\ yennita_caca@yahoo.com
}

\begin{abstract}
The main purpose of this research was to know the level of understanding of students' concepts in the sound wave and light waves material in class XI students of senior high school in the sub-district of Tampan, Pekanbaru. This research is survey research. The population in this research were all students of class XI of state Senior high schools in the Tampan sub-district of Pekanbaru, while the research sample numbered 65 students. The research instrument was in the form of concept understanding tests that were compiled based on indicators understanding the concepts of translation, interpretation, and extrapolation. The questions used were in the form of a written test in the form of multiple-choice totaling 26 items. The results of the answers to the questions given are then analyzed using descriptive analysis. The results of this research provide information, that the level of concepts understanding of class XI students in high schools throughout the sub-district of Tampan, Pekanbaru in physics lessons on sound wave material and light waves are in the very low category for the three indicators of translation, interpretation, and extrapolation. Therefore, a learning strategy is needed that is able to overcome the low understanding of the student's concepts.
\end{abstract}

Key Words: concept understanding, sound waves, light waves. 


\title{
ANALISIS PEMAHAMAN KONSEP PADA MATERI GELOMBANG BUNYI DAN GELOMBANG CAHAYA PADA SISWA KELAS XI SMA NEGERI SE-KECAMATAN TAMPAN PEKANBARU
}

\author{
Nindri Resti Nova ${ }^{* 1)}$, Fakhruddin' ${ }^{2)}$, Yennita ${ }^{3)}$ \\ ${ }^{1,2,3)}$ Pendidikan Fisika, Universitas Riau
}

\begin{abstract}
Abstrak
Tujuan utama penelitian ini adalah untuk mengetahui tingkat pemahaman konsep siswa pada materi gelombang bunyi dan gelombang cahaya pada siswa kelas XI SMA Negeri se-kecamatan Tampan Pekanbaru. Penelitian ini merupakan penelitian survei. Populasi pada penelitian ini adalah seluruh siswa kelas XI SMA Negeri se-kecamatan Tampan Pekanbaru, sedangkan sampel penelitian berjumlah 65 siswa. Instrumen penelitian berupa tes pemahaman konsep yang disusun berdasarkan indikator pemahaman konsep translation, interpretation, dan extrapolation. Soal yang digunakan berupa tes tertulis dalam bentuk pilihan ganda yang berjumlah 26 butir soal. Hasil jawaban soal yang diberikan selanjutnya dianalisis menggunakan analisis deskriptif. Hasil penelitian ini memberikan informasi, bahwa tingkat pemahaman konsep siswa kelas XI di SMAN se-Kecamatan Tampan Pekanbaru dalam pelajaran fisika pada materi gelombang bunyi dan gelombang cahaya berada pada kategori sangat rendah untuk ke tiga indikator translation, interpretation, dan extrapolation. Oleh karena itu, diperlukan suatu strategi pembelajaran yang mampu mengatasi rendahnya pemahaman konsep siswa tersebut.
\end{abstract}

Kata Kunci: pemahaman konsep, gelombang bunyi, gelombang cahaya.

\section{Pendahuluan}

Belajar merupakan suatu perubahan tingkah laku yang relatif permanen sebagai hasil dari pengalaman dalam pendidikan (Matlin dalam Nurhasanah \& Sobandi, 2016). Pendidikan itu sendiri merupakan salah satu kunci kehidupan dan kunci utama untuk menciptakan sumber daya manusia yang berkualitas. Pembelajaran IPA memerlukan suatu keterampilan dalam mengkaitkan antar konsep dan penggalian bukti. IPA sebagian besar dibangun atas dasar rasa ingin tahu (Mutveia \& Mattssonb, 2014). IPA mengandung tiga dimensi yaitu, IPA sebagai proses, IPA sebagai produk, dan IPA sebagai sikap, ketiga dimensi tersebut bersifat saling keterkaitan (Sardinah et al., 2012).

IPA sebagai produk dan proses, artinya pembelajaran yang dilakukan seharusnya mengajarkan bagaimana pengetahuan tersebut ditemukan oleh siswa itu sendiri, sedangkan guru hanya sebagai fasilitator dan pembimbing bagi siswa yang menemukan kesulitan dalam proses menemukan pengetahuannya (Putrayasa et al., 2014). IPA sebagai sikap berhubungan dengan sikap ilmiah. Setidaknya terdapat sembilan aspek sikap dari sikap ilmiah yaitu sikap ingin tahu, sikap ingin mendapat sesuatu yang baru, sikap tidak putus asa, sikap tidak berprasangka, sikap mawas diri, sikap bertanggung jawab, sikap berpikir bebas, sikap kedisiplinan diri (Sardinah et al., 2012). Pengetahuan alam tidak cukup hanya diperoleh dengan cara belajar dari buku atau sekedar mendengarkan penjelasan dari pihak lain, akan tetapi diperlukan suatu kegiatan pembelajaran yang melibatkan adanya suatu kegiatan proses untuk menghasilkan produk tertentu (Cavus \& Alhih, 2014).

Fisika merupakan salah satu mata pelajaran dalam rumpun IPA yang sangat erat kaitannya dengan kehidupan sehari-hari (Saregar, 2016). Fisika merupakan ilmu pengetahuan yang mempelajari benda-benda di alam, gejala-gejala, kejadian-kejadian alam serta interaksi dari benda-benda di alam tersebut. Gejala-gejala tersebut pada umumnya adalah apa yang dialami oleh indra kita, seperti penglihatan menemukan optik cahaya, pendengaran menemukan bunyi, panas juga dapat diamati melalui indra perasaan (Yuliani et al., 2017).

Melalui kurikulum 2013 revisi 2017, salah satu pembelajaran yang dapat mengembangkan potensi siswa, yaitu melalui 
pembelajaran fisika. Siswa mendapatkan pengalaman mengenai alam sekitar, karena ilmu fisika berlandaskan pada hasil pengamatan alam dan sebab akibatnya (Yanti et al., 2019).

Menurut Piaget, pedagogik yang baik harus melibatkan siswa dengan situasi yang mana siswa sendiri yang melakukan eksperimen. Makna yang luas dari ungkapan itu mencoba segala sesuatu untuk mencari tahu apa yang terjadi, memanipulasi benda-benda, memanipulasi simbol, mengajukan pertanyaan dan berupaya menemukan sendiri jawabannya, mencocokkan apa yang ia temukan disuatu waktu dengan apa yang ditemukan diwaktu yang lain, dan membandingkan temuannya dengan temuan siswa lain (Nur, 2011).

Salah satu aspek pada ranah kognitif yang dikemukakan oleh Bloom adalah aspek pemahaman (comprehension). Bloom dalam Ikbal et al. (2018) menjelaskan bahwa pemahaman siswa yaitu ketika mereka dihadapkan pada suatu komunikasi, siswa diharapkan dapat mengetahui apa yang sedang dikomunikasikan dan dapat menggunakan ideide yang terkandung dalam komunikasi tersebut. Pemahaman konsep dapat dibedakan menjadi tiga bagian yaitu yang pertama yaitu translasi (translation) merupakan kemampuan siswa dalam menterjemahkan konsepsi abstrak menjadi suatu model simbolik, kedua interpretasi (interpretation) merupakan kemampuan untuk mengenal dan memahami ide utama suatu komunikasi dan terakhir ekstrapolasi (extrapolation) merupakan membuat telaahan tentang kemungkinankemungkinan yang akan terjadi.

Arends dalam Trianggono (2017) menjelaskan bahwa konsep menjadi fondasi bagi pemikiran seseorang. Pemahaman konsep mengalami peningkatan karena kemampuan menalar siswa berkembang. Menurut Dahar penguasaan konsep merupakan kemampuan siswa dalam memahami makna secara ilmiah baik teori maupun penerapannya dalam kehidupan sehari-hari (Hermansyah et al., 2015). Penguasaan konsep harus menjadikan siswa tidak sekedar tahu (knowing) dan hafal (memorizing) tentang konsep, melainkan harus menjadikan siswa mengerti dan memahami (understand) konsep tersebut dan menghubungkan keterkaitan suatu konsep dengan konsep lain (Lubis, 2009).
Pentingnya seseorang menguasai suatu konsep adalah untuk memecahkan masalah, seseorang siswa harus mengetahui aturanaturan yang relevan dan aturan-aturan ini didasarkan pada konsep-konsep yang diperolehnya (Kusdiastuti et al., 2016; Holme et al., 2015). Siswa yang paham konsep lebih cepat melakukan hal-hal yang terkait dengan pengetahuan prosedural dibandingkan dengan siswa yang menghafal dan mengingat saja (Saregar, 2016). Kenyataannya hasil belajar fisika di sekolah pada umumnya masih rendah. Hal ini dikarenakan kurangnya penguasaan konsep dan lemahnya keterampilan siswa dalam berhitung (Astutik et al., 2019 ).

Penelitian yang dilakukan oleh Widya Oktaviani et al. (2017) pada salah satu SMA di Mataram menggunakan tes pilihan ganda, memperoleh hasil dengan tingkat pemahaman konsep siswa berada pada tinggkat yang rendah. Penelitian tersebut menjadi salah satu dasar untuk melakukan penelitian mengenai analisis pemahaman konsep siswa SMA kelas XI di kota Pekanbaru. Tujuan yang ingin dicapai dalam penelitian ini adalah untuk mengetahui tingkat pemahaman konsep pada materi gelombang bunyi dan gelombang cahaya pada siswa kelas XI SMA Negeri seKecamatan Tampan Pekanbaru.

\section{Bahan dan Metode}

Penelitian dilakukan di SMAN seKecamatan Tampan Pekanbaru. Populasi dalam penelitian ini adalah seluruh siswa kelas XI SMAN 12 Pekanbaru dan SMAN 15 Pekanbaru tahun ajaran 2019/2020 yang sudah mendapatkan pembelajaran gelombang bunyi dan gelombang cahaya. Adapun sampel yang diambil dalam penelitian ini berjumlah 65 siswa yang mewakili satu lokal dari setiap sekolah.

Penelitian ini termasuk penelitian survei. Dimana penelitian survei merupakan metode penelitian kuantitatif yang digunakan untuk mendapatkan data yang terjadi pada masa lampau atau saat ini. Penelitian dilakukan dengan menguji pemahaman konsep secara langsung terhadap subjek penelitian. Instrumen penelitian berupa soal tes pemahaman konsep pada materi gelombang bunyi dan gelombang cahaya. Soal berupa tes tertulis dalam bentuk 
pilihan ganda yang berjumlah 26 butir soal yang telah divalidasi.

Teknik analisis data pada penelitian ini adalah analisis deskriptif. Analisis deskriptif dalam penelitian digunakan untuk memberikan gambaran tentang pola dan tingkat pemahaman konsep translasi (translation), interpretasi (interpretation) dan ekstrapolasi (extrapolation).

Untuk tahap-tahap pemberian skor, jika jawaban benar memperoleh skor 1, jika jawaban salah memperoleh skor 0. Kemudian masing-masing skor perolehan tiap indikator dianalisis. Persentase masing-masing indikator pemahaman konsep (translation, interpretation, extrapolation) didapatkan menggunakan persamaan (1)

$$
\mathrm{NP}=\frac{\mathrm{R}}{\mathrm{SM}} \times 100 \%
$$

Keterangan :

$$
\begin{aligned}
\mathrm{NP}= & \text { Nilai pemahaman konsep } \\
\mathrm{R}= & \text { Skor yang diperoleh siswa } \\
\mathrm{SM}= & \text { Skor maksimum dari tes yang } \\
& \text { bersangkutan }
\end{aligned}
$$

Pengkategorian pemahaman konsep yang diperoleh siswa dari hasil tes dapat digunakan kriteria seperti pada Tabel 1.

Tabel 1. Kategori pemahaman konsep siswa

\begin{tabular}{ccl}
\hline No & Interval (\%) & \multicolumn{1}{c}{ Kategori } \\
\hline 1 & $90<\mathrm{x} \leq 100$ & Sangat tinggi \\
2 & $80<\mathrm{x} \leq 89$ & Tinggi \\
3 & $65<\mathrm{x} \leq 79$ & Sedang \\
4 & $55<\mathrm{x} \leq 64$ & Rendah \\
5 & $0<\mathrm{x} \leq 54$ & Sangat rendah \\
\hline
\end{tabular}

\section{Hasil dan Pembahasan}

Hasil analisis deskripstif, diperoleh persentase pemahaman konsep siswa tiap indikator terlihat pada Tabel 2. Berdasarkan Tabel 2 diketahui bahwa pemahaman konsep siswa pada indikator translation adalah sebesar 23,0\% dengan kategori pemahaman konsep sangat rendah, sedangkan indikator interpretation adalah sebesar $27,9 \%$ dengan kategori sangat rendah, dan indikator Extrapolation adalah sebesar $28,2 \%$ dengan kategori sangat rendah.

\section{Indikator Translation}

Indikator pemahaman konsep translation berkaitan dengan kemampuan siswa dalam menterjemahkan konsep abstrak yang terdapat pada materi gelombang bunyi dan cahaya menjadi bentuk simbol atau sebaliknya. Setelah diberikan tes pemahaman konsep diperoleh bahwa persentase pemahaman konsep siswa pada indikator translation yaitu $23 \%$ dengan kategori sangat rendah, hal ini

\begin{tabular}{|c|c|c|c|}
\hline No & $\begin{array}{l}\text { Kategori } \\
\text { dan proses } \\
\text { kognitif }\end{array}$ & $\begin{array}{c}\text { Persentasi } \\
\text { rata-rata } \\
\text { jawaban } \\
\text { siswa (\%) }\end{array}$ & Kategori \\
\hline 1 & Translation & 23,0 & $\begin{array}{l}\text { Sangat } \\
\text { rendah }\end{array}$ \\
\hline 2 & Interpretation & 27,9 & $\begin{array}{l}\text { Sangat } \\
\text { rendah }\end{array}$ \\
\hline 3 & Extrapolation & 28,2 & $\begin{array}{l}\text { Sangat } \\
\text { rendah }\end{array}$ \\
\hline
\end{tabular}
sejalan dengan penelitian yang telah dilakukan oleh (Anggereni, 2016).

Tabel 2. Persentase rata-rata pemahaman konsep siswa per indikator

Sub indikator translation terdiri dari menterjemahkan bentuk abstrak (soal 1-2), menterjemahkan bentuk simbol (soal 3-4), dan menterjemahkan suatu bentuk perkataan (soal 5-6). Berdasarkan hasil analisis data, persentase pemahaman konsep siswa pada masing-masing sub indikator terlihat pada Gambar 1.

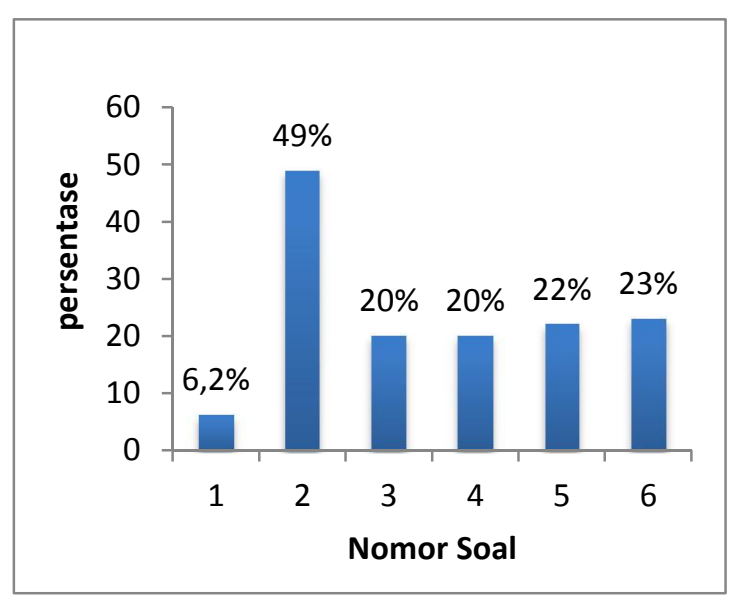

Gambar 1. Persentase pemahaman konsep indikator translation.

Berdasarkan Gambar 1. persentase pemahaman konsep terendah pada soal nomor 
1 dengan persentase pemahaman konsep sebesar $6,2 \%$. Bentuk soal dapat dilihat pada Gambar 2.

1. Dalam kehidupan sehari-hari, kita melihat gelembung air sabun akan terlihat berwarna-warni.

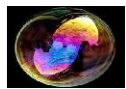

Hal ini terjadi disebabkan karna perpaduan dua gelombang cahaya yang jatuh pada gelembung air sabun. Berdasarkan pernyataan tersebut, prinsip fisika yang sesuai dengan pernyataan tersebut adalah, kecuali ...
a. Cincin Newton
b. Fatamorgana
c. Genangan oli
d. Warna burung kolibri
e. Peralihan warna pada mata uang kertas

Gambar 2. Bentuk soal indikator translation.

Siswa yang menjawab benar berjumlah 4 orang dan 61 orang menjawab salah. Dari 61 siswa yang tidak paham konsep, sebagian besar siswa tersebut menjawab (pilihan jawaban e) yaitu peralihan warna pada mata uang kertas. Untuk jawaban yang benar adalah (pilihan jawaban b) yaitu fatamorgana. Gelembung air sabun menerapkan konsep interferensi, dimana interferensi sendiri dapat didefinisikan sebagai perpaduan dua gelombang cahaya. Interferensi dapat terjadi pada lapisan tipis seperti lapisan sabun dan lapisan minyak seperti (pilihan jawaban c) yaitu genangan oli. Selain itu fenomena cincin Newton juga merupakan fenomena dari interferensi yang disebabkan oleh pemantulan cahaya diantara dua permukaan. Aplikasi dari penerapan interferensi dalam kehidupan sehari-hari lainnya dapat kita temukan pada warna burung Kolibri dan peralihan warna pada mata uang kertas.

Persentase pemahaman konsep siswa yang tertinggi terletak pada sub indikator menterjemahkan suatu abstraksi kepada abstraksi yang lain dengan persentase pemahaman konsep sebesar $49 \%$. Bentuk soal dapat dilihat pada Gambar 3. Siswa yang menjawab benar 32 orang dan siswa menjawab salah 33 orang. Pada soal ini siswa banyak menjawab (pilihan jawaban c) yaitu LED TV memiliki energi yang kecil dibandingkan LCD TV. Dari semua pilihan jawaban yang ada hanya pilihan jawaban c yang paling sesuai dengan isi tabel yang ditampilkan pada soal. Daya listrik yang dimiliki oleh LED TV paling baik dari LCD TV itu artinya LED TV lebih hemat energi dari pada LCD TV.

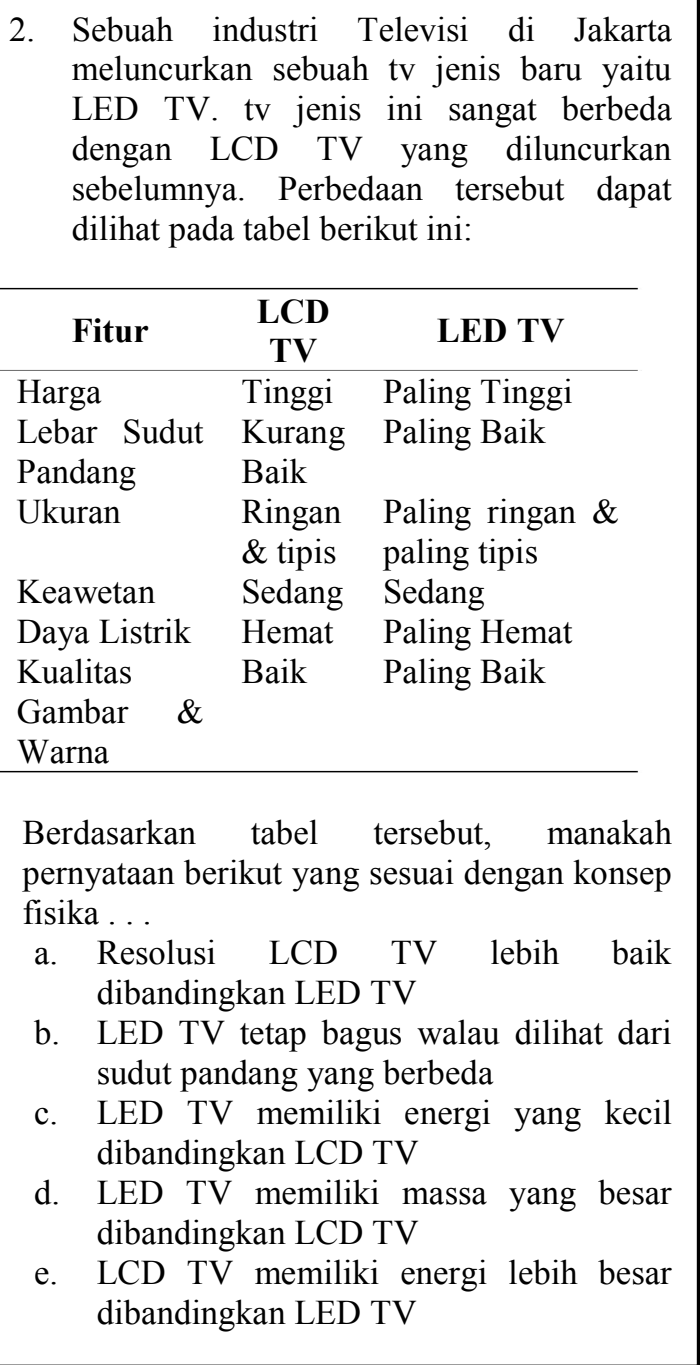

Gambar 3. Bentuk soal indikator translation.

\section{Indikator Interpretation}

Indikator pemahan konsep interpretation merupakan kemampuan untuk mengenal dan memahami ide utama suatu komunikasi. Siswa dikatakan memahami materi gelombang bunyi dan cahaya, jika dapat mengkonstruksi makna dari pesan-pesan yang ada pada materi tersebut. Setelah diberikan tes pemahaman konsep diperoleh persentase pemahaman konsep siswa pada indikator interpretation yaitu $27,9 \%$ dengan kategori sangat rendah, 
Hal ini sesuai dengan penelitian yang dilakukan oleh (Athaillah et al., 2017).

Sub indicator interpretation terdiri dari menginterpretasikan berbagai bacaan secara dalam dan jelas (soal 7-8), membedakan pembenaran atau penyangkalan suatu kesimpulan (soal 9-10), menafsirkan berbagai data sosial (soal 11-12), membuat batasan atau kualifikasi (soal 13-14). Berdasarkan hasil analisis data persentase pemahaman konsep siswa pada masing-masing sub indikator Interpretation terlihat pada Gambar 4.

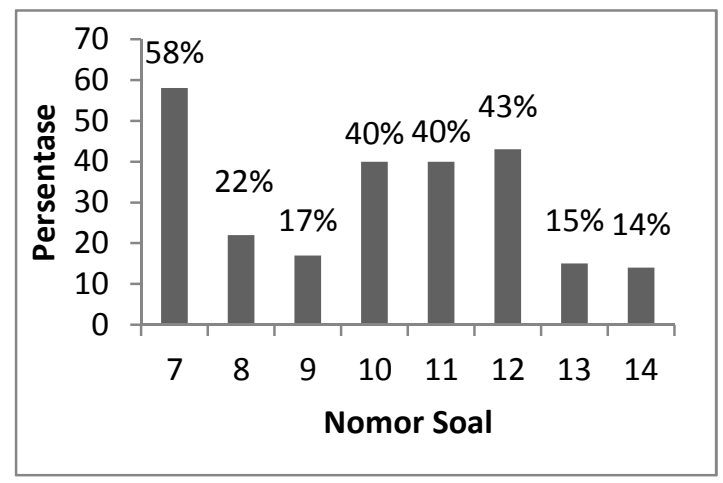

Gambar 4. Persentase pemahaman konsep indikator interpretation.

14. Massa jenis adalah ukuran kepadatan yang dimiliki oleh suatu benda.

\begin{tabular}{llc}
\hline No & $\begin{array}{l}\text { Nama } \\
\text { bahan }\end{array}$ & $\begin{array}{c}\text { Massa Jenis } \\
\left(\mathrm{g} / \mathrm{cm}^{3}\right)\end{array}$ \\
\hline 1 & Besi & $78 \mathrm{Hg} / \mathrm{dm}^{3}$ \\
2 & Perunggu & $8,7 \mathrm{Gg} / \mathrm{dam}^{3}$ \\
3 & Tembaga & $8,9 \mathrm{~g} / \mathrm{cm}^{3}$ \\
4 & Kuningan & $8.400 \mathrm{Kg} / \mathrm{cm}^{3}$ \\
\hline
\end{tabular}

Berdasarkan tabel di atas, jika bahan-bahan tersebut memiliki modulus young yang sama. Maka manakah bahan yang memiliki cepat rambat bunyi yang paling besar ...

a. Besi

b. Perunggu

c. Tembaga

d. Kuningan

e. Cepatrambat bunyi semua bahan sama besar

Gambar 5. Bentuk soal indikator interpretation.

Berdasarkan Gambar 4. persentasi pemahaman konsep terendah terletak pada sub indikator membuat batasan (kualifikasi) yang tepat ketika menafsirkan suatu data dengan persentase $6,2 \%$ dengan kategori sangat rendah. Bentuk soal dapat ditunjukkan pada Gambar 5.

Siswa yang menjawab dengan benar hanya 9 siswa dan yang menjawab salah 56 siswa. Kebanyakan dari siswa menjawab (pilihan jawaban e) yaitu Cepat rambat bunyi semua bahan sama besar. Sedangkan jawaban yang benar adalah (pilihan jawaban a) yaitu besi. Alasannya adalah, karena cepat rambat bunyi di dalam zat padat berbanding terbalik dengan akar dari massa jenis.

Persentase pemahaman konsep tertinggi terletak pada sub indikator pemahaman konsep memahami dan menginterpretasikan berbagai bacaan secara dalam dan jelas dengan persentase pemahaman konsep sebesar $58 \%$. Bentuk soal dapat dilihat pada Gambar 6.

7. Mengisi liburan tahun baru, anggota pecinta alam di Pekanbaru mengunjungi kota Martapura di Kalimantan Selatan. Martapura menjadi salah satu daerah Di Indonesia yang menjadi tempat penghasil berlian. Mereka melihat berlian tersebut memancarkan kilauan kilauan yang indah.

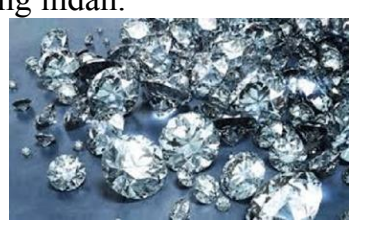

Peristiwa tersebut disebabkan oleh ...

a. sudut biasnya $0^{\circ}$

b. sudut biasnya mencapai $90^{\circ}$

c. sudut bias melebihi $90^{\circ}$

d. Sudut datang sama dengan sudut kritisnya

e. Sudut datang kecil dari sudut kritisnya

\section{Gambar 6. Bentuk soal indikator} interpretation.

Siswa yang menjawab dengan benar hanya 38 orang dan yang menjawab salah 37 orang. Jawaban yang benar (pilihan jawaban c) yaitu sudut bias lebih $90^{\circ}$. Alasannya adalah ketika seberkas sinar mengenai sebuah permukaan (udara-berlian). Jika sinar yang mengenai permukaan dengan berbagai sudut (kecil dari sudut kritis atau kecil dari $90^{\circ}$ ), maka sinar akan dibelokkan menjauhi garis normal. Namun ketika sudut datang lebih besar dari sudut kritis, maka tidak akan ada sinar yang dibiaskan. Semua energi akan 
dipantulkan. Fenomena ini disebut sebagai pemantulan total.

\section{Indikator Extrapolation}

Indikator pemahan konsep extrapolation merupakan kemampuan pemahaman yang menuntut kemampuan intelektual yang lebih tinggi, seperti membuat telaah tentang kemungkinan apa yang akan berlaku, setelah diberikan tes pemahaman konsep diperoleh bahwa persentase pemahaman konsep siswa pada indikator extrapolation yaitu 28,2\% dengan kategori sangat rendah. Hal ini sejalan dengan penelitian yang dilakukan oleh (Athaillah et al., 2017).

Sub indikator extrapolation terdiri dari kemampuan menarik kesimpulan pernyataan yang eksplisit (soal 15-16), menggambarkan kesimpulan dan menyatakannya secara efektif (soal 17-18), menyisipkan suatu data dilihat dari kecendrungannya (19-20), memperkirakan konsekuensi suatu bentuk komunikasi yang digambarkan (21-22), peka terhadap faktor-faktor yang dapat membuat prediksi tidak akurat (23-24), membedakan nilai pertimbangan dan suatu prediksi (25-26). Berdasarkan hasil analisis data persentase pemahaman konsep siswa pada masing-masing sub indikator extrapolation terlihat pada Gambar 7.

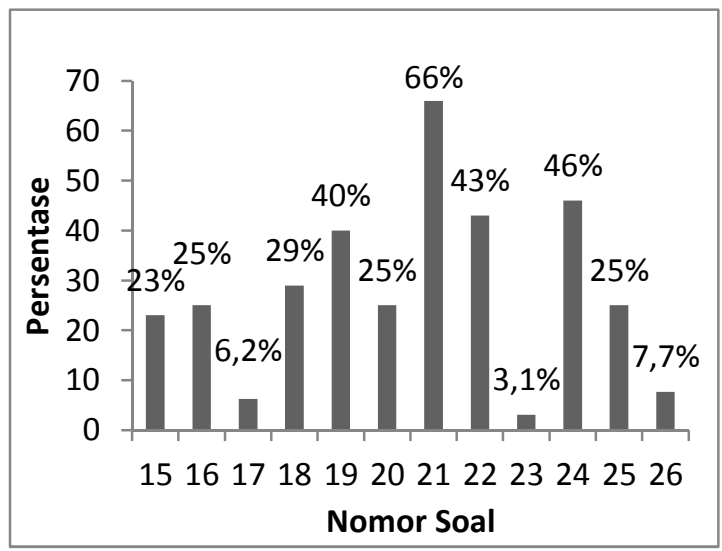

Gambar 7. Persentase Pemahaman Konsep Indikator Extrapolation.

Berdasarkan Gambar 7. persentase pemahaman konsep terendah terendah terletak pada sub indikator kemampuan menyisipkan suatu data dalam sekumpulan data dilihat dari kecenderungannya dengan persentase 3,1\%. Bentuk soal nomor 23 dapat dilihat pada Gambar 8. Siswa yang menjawab dengan benar hanya 2 siswa dan 63 siswa menjawab salah. Kebanyakan dari siswa menjawab (pilihan jawaban d) yaitu mengubah jarak L menjadi 2 kali semula. Jawaban yang benar adalah (pilihan jawaban d) yaitu mengubah $d$ menjadi 2 kali semula. Alasannya adalah Jarak pita terang ke-n dari terang pusat dapat ditulis dalam persamaan $\mathrm{dp} / \mathrm{L}=\mathrm{n} \lambda$. Untuk mengubah nilai $\mathrm{p}$ menjadi $2 \mathrm{~mm}$ yang harus dilakukan adalah mengubah d menjadi 4 kali semula.

23. Percobaan celah Young dapat dilihat seperti gambar berikut ini

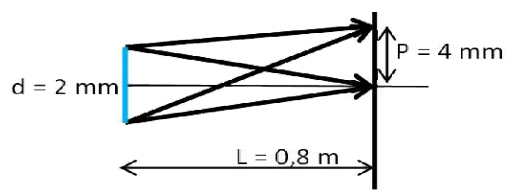

$\mathrm{P}$ adalah jarak terang antara terang pusat dengan terang pertama. Jika nilai $\mathrm{P}$ di ubah menjadi $2 \mathrm{~mm}$. Upaya yang dapat dilakukan adalah ...

a. Mengubah sumber cahaya yang memiliki panjang gelombang 2 kali semula

b. Mengubah jarak L menjadi 2 kali semula

c. Mengubah jarak L menjadi 4 kali semula

d. Mengubah d menjadi 2 kali semula

e. Mengubah d menjadi 4 kali semula

\section{Gambar 8. Bentuk soal indikator extrapolation.}

Persentase pemahaman konsep tertinggi terletak pada sub indikator pemahaman konsep pada kemampuan untuk mem-perkirakan konsekwensi dari suatu bentuk komunikasi dengan persentase $66 \%$. Bentuk soal dapat dilihat pada Gambar 9. Siswa yang menjawab dengan benar berjumlah 43 siswa. Siswa menjawab (pilihan jawaban b) yaitu 1) dan 3). Alasannya adalah, cepat rambat gelombang pada tali dipengaruhi oleh faktor-faktor seperti, gaya tegangan tali dan massa persatuan panjang tali. Untuk soal lainnya diperoleh persentase pemahaman konsepnya antara 3,1\% sampai $46 \%$ dengan kategori pemahaman konsep siswa berada pada tingkat yang rendah. 


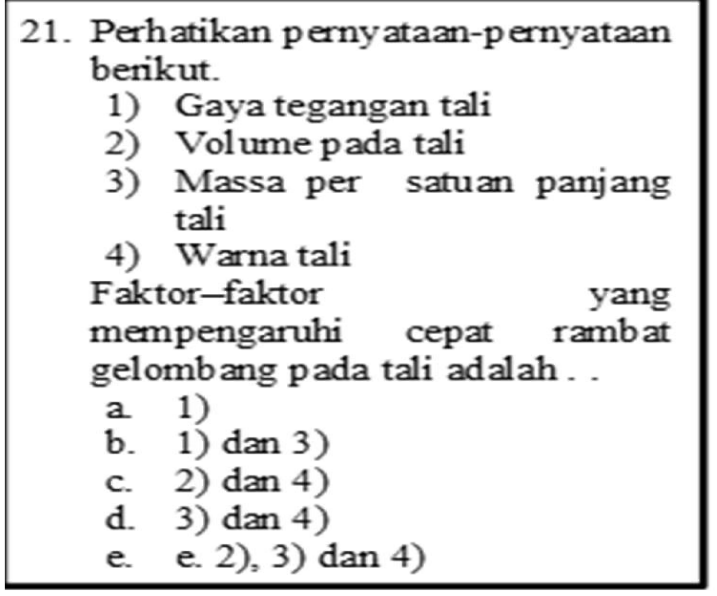

Gambar 9. Bentuk soal indikator extrapolation.

Hasil ini didukung oleh kajian Widya Oktaviani et al. (2017) dengan kemampuan pemahaman konsep rata-rata 49,33\% kategori rendah. Hasil survei ditemukan bahwa, pada umumnya siswa kelas XI SMA Negeri seKecamatan Tampan Pekanbaru, masih berada pada tahap sangat rendah tingkat pemahaman konsepnya, berdasarkan indikator translation, inter-pretation, extrapolation. Hanya pada indikator extrapolation, dimana pemahaman konsep siswa sedikit mengalami peningkatan. Oleh karena itu, perlu dicari solusi bagi mengatasi rendahnya pemahaman konsep terutama pada konsep gelombang bunyi dan gelombang cahaya, dalam rangka meningkatkan kualitas pendidikan di Sekolah Menengah Atas, khususnya yang berlokasi di Kecamatan Tampan Pekanbaru.

\section{Kesimpulan dan Saran}

Berdasarkan hasil penelitian yang telah dilakukan dalam upaya mengetahui pemahaman konsep siswa pada materi gelombang bunyi dan gelombang cahaya dapat disimpulkan bahwa tingkat pemahaman konsep siswa kelas XI SMA Negeri seKecamatan Tampan Pekanbaru berada pada kategori sangat rendah. Tingkat pemahaman konsep siswa berdasarkan indikator yang digunakan yaitu, indikator translation berada pada kategori sangat rendah, indikator interpretation berada pada kategori sangat rendah, dan indikator extrapolation juga berada pada kategori sangat rendah.
Berdasarkan hasil penelitian, disarankan agar guru dapat mengembangkan strategi pembelajaran yang sesuai, guna untuk meningkatkan pemahaman konsep siswa terutama pada materi gelombang bunyi dan gelombang cahaya. Strategi yang digunakan oleh guru diharapkan lebih menekankan kepada kegiatan pembelajaran yang mampu membantu siswa untuk memahami konsep dalam bentuk tabel dan grafik, mengaitkan antar konsep fisika, dan mengaitkan antara konsep yang telah dipelajari terhadap penerapannya dalam kehidupan sehari-hari, serta contoh-contoh aplikasi fisika didalam kehidupan sehari-hari.

\section{Daftar Pustaka}

Anggereni, S. (2016). Efektivitas pembelajaran menggunakan media pembelajaran macro media flash dalam meningkatkan pemahaman konsep fisika materi hukum Newton, Jurusan Pendidikan Fisika Fakultas Tarbiyah dan Keguruan, UIN Alauddin Makassar. Jurnal Biotek, 4(2).

Astutik, S., Lesmono, A.D., \& Adani, D.A.L. (2019). Pengaruh model collaborative creativity (CC) terhadap kemampuan literasi sains dan hasil belajar fisika siswa di SMA. Jurnal Pembelajaran Fisika, 21(1), 9-22, Januari 2019.

Athaillah, Khaldun, I., \& Mursal. (2017). Peningkatan pemahaman konsep siswa melalui laboratorium virtual pada materi listrik dinamis di SMA Negeri 1 Sukamakmur Aceh Besar. Jurnal Pendidikan Sains Indonesia, 05(01), 114119.

Cavus, N., \& Alhih, M.S. (2014). Learning management systems use in science education. Social and Behavioral Sciences, 2(1), 517-520.

Hermansyah, Gunawan, \& Herayanti, L. (2015). Pengaruh penggunaan laboratorium virtual terhadap penguasaan konsep dan kemampuan berpikir kreatif siswa pada materi getaran dan gelombang. Jurnal Pendidikan Fisika dan Teknologi, 1(2), April 2015. ISSN. 2407-6902,

Holme, T.A., Luxford, C.J., \& Brandriet, A. (2015). Defining conceptual understanding in general chemistry. Journal of Chemical Education, 92(9), 1477-1483. 
Ikbal, M.S., Nurhayati, \& Ahmad, Y. (2018). Pengaruh metode guided inquiry dan pengetahuan operasi dasar matematika dalam praktikum fisika dasar terhadap pemahaman konsep fisika mahasiswa Pendidikan Fisika UIN Alauddin Makassar. Jurnal Al-Ta'dib, 11(1).

Kusdiastuti, M., Harjono, A., Sahidu, H., \& Gunawan. (2016). Pengaruh model pembelajaran inkuiri berbantuan laboratorium. Jurnal Pendidikan Fisika dan Teknologi, 2(3), Juli 2016. ISSN. 2407-6902.

Lubis, I.L. (2009). Tingkatan pemahaman mahasiswa pada konsep fisika. Media Infotama, 4(8), 14-22.

Mutveia, A. \& Mattssonb, J.E. (2014). Big ideas in science education in teacher training program. IOSTE BORNEO 2014. Procedia - Social and Behavioral Sciences, 167, pp. 190-197.

Nur, M. (2011). Model pembelajaran berdasarkan masalah. Surabaya: Pusat Sains dan Matematika Sekolah UNESA.

Nurhasanah, S., \& Sobandi, A. (2016). Minat belajar sebagai determinan hasil belajar siswa. Jurnal Pendidikan Manajemen Perkantoran, 1(1), 135 - 142.

Putrayasa, I.M., Syahruddin, \& Margunayasa, I.G. (2014). Pengaruh model pembelajaran discovery learning dan minat belajar terhadap hasil belajar IPA siswa. Jurnal Mimbar PGSD Universitas Pendidikan Ganesha, 2(1).

Sardinah, Tursinawati, \& Noviyanti, A. (2012). Relevansi sikap ilmiah siswa dengan konsep hakikat sains dalam pelaksanaan percobaan pada pembelajaran IPA di SDN Kota Banda Aceh. Jurnal Pendidikan Serambi Ilmu, 13(2). Edisi September 2012,

Saregar, A. (2016). Pembelajaran pengantar fisika kuantum dengan memanfaatkan media PhET simulation dan LKM melalui pendekatan saintifik: Dampak pada minat dan penguasaan konsep Mmahasiswa. Jurnal Ilmiah Pendidikan Fisika AlBiruni, 5(1), 53-60. https://doi.org/ 10.24042/jpifalbiruni.v5i1.105.

Trianggono, M.M. (2017). Analisis kausalitas pemahaman konsep dengan kemampuan berpikir kreatif siswa pada pemecahan masalah fisika. Jurnal Pendidikan Fisika dan Keilmuan (JPFK), 3(1), 1-12.

Widya Oktaviani, Gunawan, dan Sutrio. 2017. Pengembangan bahan ajar fisika kontekstual untuk meningkatkan penguasaan konsep siswa. Jurnal Pendidikan Fisika dan Teknologi, ISSN. 2407-6902, 3(1), Juni 2017.

Yanti, Y., Masril, Hidayati, \& Yenni Darvina, Y. (2019). Pengaruh penerapan lks virtual laboratory dalam pembelajaran konstruktivisme terhadap pencapaian kompetensi fisika siswa kelas XI SMAN 15 Padang. Jurusan Fisika, FMIPA Universitas Negeri Padang. Pillar of Physics Education, 12(1), 153-160.

Yuliani, H., Mariati, Yulianti, R., \& Herianto, C. (2017). Keterampilan berfikir kreatif pada siswa sekolah menegah di Palangka Raya menggunakan pendekatan saintifik. Jurnal Pendidikan Fisika dan Keilmuan (JPFK), 3(1):48-56. ISSN 2442-8868. 